\title{
Factors Influencing Training and Development in the Auto-Ancillary Industries
}

\author{
S. M. Karthikeyan
}

\begin{abstract}
The $21^{\text {st }}$ century presents ample evidence that hint towards extraordinary changes that have occurred in the environment which has added a novel impetus to businesses and warrants the need to integrate training and development within the overall strategy of the organization with a view to make sure that the business thrives in the competitive market and at the same time facilitates growth. This facet implies that there is a need for employees to be regularly trained with a view to enhance their skills considering the fact that changes are occurring throughout the workforce each and every day (Pearce, 2000).

Akin to any other organization, organizations from the auto-ancillary sector too has a vision and a decree of where they ultimately intend to be. Simply said, auto-ancillary industries need to continuously evaluated their existing position and understand the kind of changes that are required to help them reach where they expect to eventually reach. The American Society for Training and Development (ASTD) indicated that organizations within the United States have been known to spend around $\$ 156$ billion per year on an average to facilitate the training and development of their employees (Miller, 2017).
\end{abstract}

While the significance of training and development is well known, there are certain factors that influence training and development within an organization. Thus, factors that influence training and development within the auto-ancillary industries would be the focus of this paper.

An attempt is made in this paper to discuss about the factors influencing the training and development especially related with Human Resources.

\section{INTRODUCTION}

The $21^{\text {st }}$ century presents ample evidence that hint towards extraordinary changes that have occurred in the environment which has added a novel impetus to businesses and warrants the need to integrate training and development within the overall strategy of the organization with a view to make sure that the business thrives in the competitive market and at the same time facilitates growth. This facet implies that there is a need for employees to be regularly trained with a view to enhance their skills considering the fact that changes are occurring throughout the workforce each and every day (Pearce, 2000). In case the organization does not match pace with the changes that take place, there is every possibility that the organization is unable to meet its business objectives and eventually becomes defunct. By facilitating regular training and development within an organization, organizations have the chance to gain a competitive advantage in the continuously changing environment.

Revised Manuscript Received on July 05, 2019

S. M. Karthikeyan, School of Management, SRM Institute of Science and Technology, Kattankulattur, Chennai, Tamizhnadu, India .
In an organization, to strive in the market field, the role of employee is vital. Also considering the auto ancillary industry, this point holds strong. This paper depicts various factors influencing the necessity of employee and the modes for training and development.

Akin to any other organization, organizations from the auto-ancillary sector too has a vision and a decree of where they ultimately intend to be. Simply said, auto-ancillary industries need to continuously evaluated their existing position and understand the kind of changes that are required to help them reach where they expect to eventually reach. At the same time it is also imperative that they match pace with the largely uncertain environment where changes constantly occur in the economic, social, political and technological environments. The American Society for Training and Development (ASTD) indicated that organizations within the United States have been known to spend around $\$ 156$ billion per year on an average to facilitate the training and development of their employees (Miller, 2017).

The focus of training is to facilitate short-term skills and knowledge that allow employees within an organization to efficiently execute their present tasks. At the same time, development activities are more focused on long-term goals that equip the employee to accept additional responsibilities in future (Nwokocha, 2015). Considering the fact that human resources within an organization is the most significant as well as dynamic resources held by an organization, the advantages presented by training and development would lead to an improvement in rendering service to customers, facilitate higher rates of employee commitment, enhance the skill levels, develop the experience and knowledge of employees which leads to a marked increase in productivity (Walsh et al., 2010).

While the significance of training and development is well known, there are certain factors that influence training and development within an organization. This paper will attempt to identify human related factors that influence organizations to adopt and execute training and development.

A study conducted by Bhasker (2013) indicated that auto-ancillary industries are exposed to a crucial challenge with regards to skilled manpower and an innate capability to compete on a global level. The author concluded that within the auto-ancillary industry human resources were not appropriately handled elucidating factors such as unfavorable working conditions, dismal or no training opportunities, low remuneration and level of education caused a high rate of employee turnover. 
As a factor, human relation is also instrumental in influencing training and development within organizations. According to Burma (2014), it is imperative for managers to establish and maintain excellent human relations thereby rendering training and development as a primary condition that helps in problems related to humans.

Another study by Bercu (2017) also revealed that the exposure of employees to training can increase job satisfaction. Moreover, employees who are subject to training and development programmes are in a better position to develop their self-esteem and lead to higher levels of job satisfactions.

Providing periodic training and development for employees is not only beneficial in enhancing the employee productivity, job satisfaction and motivation but it also boosts their self-perception, self-confidence while bringing down level of anxiety and a sense of insufficiency.

Thus, factors that influence training and development within the auto-ancillary industries would be the focus of this paper which brings us to the research objectives.

- To examine factors that influence training and development in auto-ancillary industry

- To recommend strategies to improve training and development in auto-ancillary industry

An attempt is made in this paper to discuss about the factors influencing the training and development especially related with Human Resources.

\section{RESEARCH METHODOLOGY}

Since this is a review paper, the research was conducted by perusing prominent research papers in leading educational databases such as Elsevier, Science Direct, Taylor and Francis and other significant journals that related to social and organizational research have been extensively evaluated to cover the scope of this paper. With a view to add further relevance to the existing review, research papers published most recently as in the past were equally considered in order to emphasize latest developments. Lexicons that were closely associated with influencing factors have been largely utilized to arrive at appropriate results.

The main objective of a review paper is to identify all the researches that were published in the past in line with the research objectives. Nonetheless, writing a review paper is often challenged with any modification from the perspective of how a present research has been published and how multiple elements of the research is described in the literature or categorized by organizations.

An attempt is made in this paper to discuss about the factors influencing the training and development especially related with Human Resources.

\section{FACTORS INFLUENCING TRAINING AND DEVELOPMENT}

\section{Seasonal Demand}

Success of any industry including the auto-ancillary industry depends on the training provided to the work force. The auto-ancillary industry serves the automotive industry and the automotive industry is subject to many fluctuations in demand. These fluctuations in demand are usually seasonal and during peak season the demand for automobiles go up whereas there is a drop at other times (Atieno, 2015). To meet the demand of peak season, the auto ancillary industry needs to certainly consider training and development of their employees. Since the auto ancillary industry is also fraught with issues relating to labour, training and development of employees can be an effective way to manage labour related challenges and the auto ancillary industry can certainly gain from training and development programmes. Training the work force of seasonal demand is really a challenging task of any Management.

\section{Performance Enhancement}

Training and development is an area that is intrinsically associated with organizational operations with a focus on enhancing individual as well as organizational performance. In other words, it is also termed as human resources development which means developing the human resources within an organization to ensure the competency of the organization in their target market. The focus of training is on initiating activities in the present day in order to facilitate the development of personnel to execute their existing tasks as well as to enable them with a skill advantage that will allow them to execute their tasks tomorrow (Vinesh, 2014). Thus, it can be said that training can enhance the overall performance of the organization which in turn gives the much needed impetus to organizations to initiate and execute training activities within their organizations. The performance of the organization indeed depends on performance enhancement of the every employee's in the organization and the need for training in an organization is thus inevitable.

\section{Human Relations}

Another factor that influences training and development within organizations is the human relations factor. Organizations that provided regular training to their employees have witnessed an increase in recruitment, productivity and an employee turnover rate that was comparatively low (Kusluvan, 2003). This is attributed due to the human relations that are established when training is provided and the values employees receive during the course of their training.Providing training to staff members not only improves their productivity, job satisfaction and motivation but it also leads to a boost in the self-perception and self-confidence of employees while bringing down anxiety and inadequacy levels.

A study conducted by Atieno (2015) indicated that human relations can play a critical role in influencing training within organizations. According to the study, it was revealed that factors relating to human relations like the need to improve the process of motivation, necessity to enhance the self-esteem and self-confidence, the requirement for a learning environment that is healthy and the need to have enhanced team work within organizations can have a major influence on training within organizations. By carrying out quality training inculcating human relation values that follows the organizational goal will elevate the position of the organization with high turn around. 


\section{Personal Characteristics}

Personal characteristics of employees are yet another factor that is instrumental in influencing training and development initiatives within organizations. An organization might opt to provide training on the basis of the personal characteristics of employees such as; gender, age, ethnicity etc. (Anderson et al., 2008). Different traits indicate the level of acceptance of employees towards training.

To systematically manage the employees the organization should also deal with the individualistic characterization of the human labor. The individual characteristics of employees can be termed as a focused effort by an employee to effectively utilize the training that has been imparted with a view to impact the organizational outcomes. There are several individual characteristics that have been identified by researchers in the past that can influence the process of training (Suleiman et al., 2016). These individual characteristics would comprise of job satisfaction, organizational cynicism, engagement with the job, and organizational commitment. Further, the effectiveness of training can also be influenced by the attitude, expectations, values and interests of individuals. Individual characteristics would also include traits such as cognitive ability, conscientiousness, self-efficacy, anxiety, motivation and achievement (Madagamage et al., 2014). Since it is difficult to consolidate all these personal traits for the strategic training, the organization choses the individual characteristic suitable for their firm.

\section{Prior Education}

For the betterment of the organization, if the employee can gather prior minimum information about the working, the employer can deal the work process legibly and smoothly with his employee. Several authors are of the opinion that employees who are better educated have more scope to receive further opportunities for training. Having a well-educated workforce is an intrinsic factor that influences whether the organization will initiate training programmes. This is due to the fact that employees who are educated are in a better position to understand and grasp concepts better which will add much value to their day to day functionalities (Maurer, 2015). This is particularly true in the case of auto-ancillary industries where a large number of workers are uneducated and are engaged in executing their day to day activities on the shop floor. Prior education is very much required to understand the technical related factors and its impact on the finished product of the organisation. Hence, the prior education also plays the vital role in the influencing the factors of training and development.

\section{Workforce Mobility}

The propensity of the workforce to continuously shift renders it difficult to establish trust-based relations at work. In such situations it is imperative that organizations establish trust based relationships and create engagement with employees by facilitating regular training (Juhdi et al., 2010). Regular training can enrich the working experience of the employee as they will be benefitting from the learning that they acquire which will be utilized by them to improve the organizational outcomes while augmenting their knowledge. Minimum is the mobility of work force, maximum is the time an employer has to bind a healthy engagement with the work force. As mentioned earlier, an organization with frequent workforce mobility takes a huge time to focus on development. Thus, mobility of the workforce is one of the key factors that drive organizations to initiate training activities for their personnel.

\section{Human Resource Practices}

Human resource practices that are being followed in specific work environments present a significant setting within which training can be conducted. These HR practices play an intrinsic role in mediating the impact that training can have (Shaukat et al., 2015). Literature pertaining to this aspect (Fook et al., 2015) indicates that extensive training or increasing the number of training might not be effective if the strategies used for human resources are not in alignment with the training activities. Human Resoure practices involves from recruitment to exit of employees in the organisation. It plays the important role to choose the right employees with right prior education, personal characteristics, conducting required training for performance enhancement of employee and organisation.

\section{FACTORS INFLUENCING TRAINING AND DEVELOPMENT IN THE AUTO ANCILLARY INDUSTRY}

Considering all the above factors to healthily promote human relation with the organization, to be a part of an auto ancillary industry requires researching all the factors resulting in a profit goal. Combining the advantage and disadvantage of all the factors, the following outcomes are made. To meet the seasonal demand, organizations have to upgrade the skill levels of employees, but upgrading the skill level of employees would depend on their existing level of education. Again the meeting the seasonal demand is to ensure that the organizational performance is improved however, organizational performance can only be improved if periodic changes in the workplace are affected. All these factors are thus intricately related and necessitate the need for training.

\section{CONCLUSION}

On a whole, several factors influence the necessity of training and development to the employees. For the efficient promotion of the organization in the competitive market, this paper has successfully dealt the factors driving the human force to the working process. This factors in one or the other way, positively promote the growth of the auto ancillary industry keeping on account the demand, performance and human values. The seven factors that have been discussed within this paper are the most common ones that are applicable across industries, however; only three of the factors viz., seasonal demand, performance enhancement, and prior education are instrumental in influencing training within the auto ancillary industries. Other factors are still relevant since no organization run without the basic knowledge about their employee's traits and goals to make them the

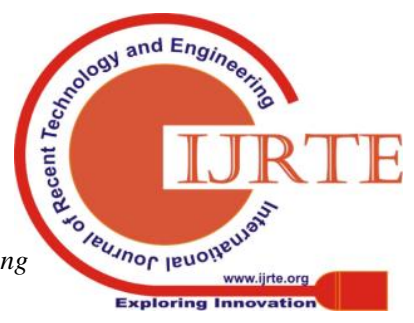


organizational goals. Rather than concentrating these factors for the holistic training and development of employees, various other factors should also be considered. Other factors of Human Relations, Human resources and work force mobility are well managed by many organizations. Personal characteristics also need to be given equal priority in the important influencing factors of training and development. Overall, developing suitable workforce to meet the seasonal demand, performance enhancement of employee to achieve the organization's performance enhancement, base of prior education considering the long term vision of organizations are important. We discussed about the factors influencing the training and development especially related with Human Resources.

\section{REFERENCES}

[1] Anderson, C., Spataro, S.E. \& Flynn, F.J., Personality and organizational culture as determinants of influence. Journal of Applied Psychology. [Online], 93(3). 702-710 (2008). Available from: http://doi.apa.org/getdoi.cfm?doi=10.1037/0021-9010.93.3.702.

[2] Atieno, J.I., Factors Influencing Staff Training And Development Decisions In State-Owned Hotels In Western Kenya. [Online], University of Nairobi (2015). Available from: http://erepository.uonbi.ac.ke/bitstream/handle/11295/94606/Atieno_ Factors influencing staff training and development decisions in state-owned hotels in western Kenyapdf?sequence $=1$.

[3] Bercu, A.-M., Impact of employees' training programmes on job satisfaction, Current Science. [Online], 112(7), 1340 -1345 (2017). Available

from: http://www.currentscience.ac.in/Volumes/112/07/1340.pdf.

[4] Bhasker, V.V., Indian Auto Component Industry: A Decade of Growth and Way Forward. Research Journal of Management Sciences [Online], 2 (3). 19-27 (2013). Available from: http://www.isca.in/IJMS/Archive/v2/i3/4.ISCA-RJMS-2013-014.pdf.

[5] Burma, Z.A., Human Resource Management and Its Importance for Today's Organization. International Journal of Education and Social Science [Online], 1(2), 85-94 (2014). Available from: http://www.ijessnet.com/wp-content/uploads/2014/09/9.pdf.

[6] Fook, C.Y., Sidhu, G.K., Narasuman, S., Fong, L.L., Basree, S. \& Rahman, A., 7th International Conference on University Learning and Teaching (InCULT 2014) Proceedings: Educate to Innovate [Online], London: Springer (2015). Available from: https://books.google.co.in/books?id=trpPCwAAQBAJ\&dq=increased + levels+of+training+may+be+ineffective+without+a+surrounding $+c$ ontext+of+flexible+human+resource+strategies\&source=gbs_navlink S_s.

[7] Juhdi, N., Pa'Wan, F., Othman, N.A. \& Moksin, H., Factors Influencing Internal And External Employability Of Employees. Business and Economics Journal. [Online], 2010(11), 1-10 (2010). Available

from: http://astonjournals.com/manuscripts/Vol2010/BEJ-11_Vol.2010.pdf

[8] Kusluvan, S., Managing Employee Attitudes and Behaviors in the Tourism and Hospitality Industry [Online], New York: Nova Publishers (2003). Available from: https://books.google.co.in/books?id=eQp1t_lHgzwC\&dq=Employers +who+provide+training+indicate+improved+recruitment,+increased +productivity,+reduced+turnover\&source=gbs_navlinks_s.

[9] Madagamage, G.T., Warnakulasooriya, B.N.F. \& Wickramasuriya, H.V.A., Factors Influencing Motivation to Transfer Training: An Empirical Study of a Government Sector Training Program in Sri Lanka. Tropical Agricultural Research. [Online], 26 (1), 12 - 25 (2014). Available from: https://www.pgia.ac.lk/files/Annual_congress/journel/v26/Journal-No 1/Papers/2. Ms.G.T. Madagamage - 3 - OK.pdf.

[10] Maurer, R., Higher Paid, More Educated Workers Receive More Job Training. [Online]. 2015. shrm. Available from: https://www.shrm.org/resourcesandtools/hr-topics/talent-acquisition/p ages/workers-receive-more-job-training.aspx. [Accessed: 21 June 2017].

[11] Nwokocha, I., The Validity of Effectiveness of Training and Development in Organizations in Nigeria, IOSR Journal of Business and Management. [Online], 17 (5), 01-08 (2015). Available from:
http://iosrjournals.org/iosr-jbm/papers/Vol17-issue5/Version-2/A017 520108.pdf.

[12] Pearce, J.A., Strategic management : formulation, implementation, and control [Online], Boston: Irwin/McGraw-Hill (2000). Available from: http://trove.nla.gov.au/work/6094219?q\&sort=holdings+desc\&_=149 $8032816806 \&$ versionId=39748747.

[13] Shaukat, M.H., Ashraf, M.N. \& Ghafoor, S., Impact of Human Resource Management Practices on Employees Performance. Middle-East Journal of Scientific Research [Online], 23(2), 329-338 (2015). Available from https://pdfs.semanticscholar.org/6acb/e7db4c572ce76d8238237c0f78 4ce5ff3cda.pdf.

[14] Suleiman, W., Dassanayake, M.S. \& Othman, A.E.A., Roles of Trainee Characteristics and Work Environment in Training Transfer: A Conceptual Extension of Baldwin and Ford Model with Job Attitude Factors in Nigerian Context. Amity Journal of Training and Development [Online], 1 (1), 20-31 (2016). Available from: http://amity.edu/UserFiles/admaa/243Paper 2.pdf.

[15] Vinesh, Role of Training \& Development in an Organizational Development. International Journal of Management and International Business Studies. [Online], 4(2), 213-220 (2014). Available from: https://www.ripublication.com/ijmibs-spl/ijmibsv4n2spl_13.pdf.

[16] Walsh, K., Sturman, M.C. \& Longstreet, J., Key Issues in Strategic Human Resources. In: C. Enz (ed.). The Cornell School of Hotel Administration handbook of applied hospitality strategy [Online], CA CA: SAGE, 394-414 (2010). Available from http://scholarship.sha.cornell.edu/cgi/viewcontent.cgi?article $=1244 \&$ context=articles. 